\title{
Search for the possibility of utilizing the differences in complex-forming capacities of alkylimidazoles for selective extraction of some metal ions from aqueous solutions
}

\author{
Elżbieta Radzymińska-Lenarcik \\ Department of Inorganic Chemistry, University of Technology and Life Sciences, ul. Seminaryjna 3, 85-326 Bydgoszcz, \\ Poland, e-mail: elaradz@utp.edu.pl
}

\begin{abstract}
Alkyl substituents in position 1 of the imidazole ring distinctly affect the hydrophobic properties of the molecule and strengthen its basicity. Hence, 1-alkylimidazoles have been used as extractants of a number of metal ions. Again, a methyl substituent in position 2 of the imidazole ring raises by an order of magnitude the basicity. At the same time, the substituent impedes the formation of the 2-alkylimidazole complexes with metal ions due to the steric effect.

By the substitution of alkyl groups in position 1 or 2 of the imidazole ring it is possible to program the extraction properties of extractants and to control the selectivity of extraction.
\end{abstract}

Keywords: selective extraction, alkyl imidazole derivatives, transition metals ions.

\section{INTRODUCTION}

Imidazole (Fig. 1) belongs to the family of 5-membered heterocyclic bases known also as azoles. Its molecule is planar, of aromatic character, and fairly stable thermally.

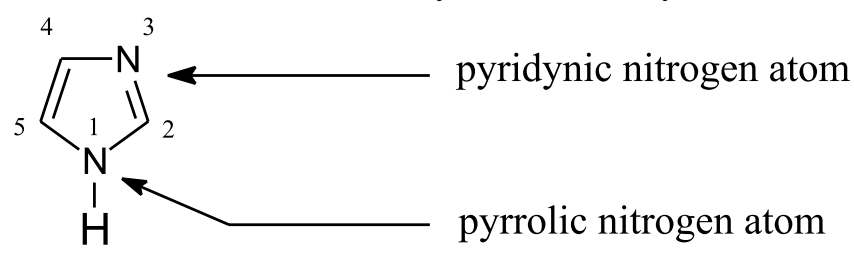

Figure 1. Structure of imidazole

Owing to the presence of the nitrogen atom in position 3, imidazole is a base $\left(\mathrm{pK}_{\mathrm{a}}\right.$ 7.12) stronger than pyridine $\left(\mathrm{pK}_{\mathrm{a}}\right.$ 5.31) but weaker than ammonia $\left(\mathrm{pK}_{\mathrm{a}} 9.63\right){ }^{1}$

According to Pearson's classification, imidazole is a base of intermediate strength. Accordingly, it can form stable complexes with either similar in strength or soft Lewis acids. ${ }^{2}$ Substitution of an alkyl in position 1 strengthens the basicity of the nitrogen atom only slightly. 1-Alkylimidazoles are the weakest bases among all the 1-, 2-, 4-, and 5-monoalkyl derivatives of 1,3-diazole. ${ }^{3}$ The water solubility of these bases and their complexes decreases sharply with increasing the alkyl chain length. Sparingly water-soluble alkylimidazoles have been suggested as the extractants for the solvent extraction of $\mathrm{Co}(\mathrm{II}), \mathrm{Ni}(\mathrm{II})$, $\mathrm{Cu}(\mathrm{II}), \mathrm{Zn}(\mathrm{II})$ and $\mathrm{Cd}(\mathrm{II}){ }^{4,5}$ The 1-alkylimidazole (alkyl ranging from $\mathrm{CH}_{3}$ through $\mathrm{C}_{4} \mathrm{H}_{9}$ ) complexes with d-electron metals were studied by Lenarcik and co-workers. ${ }^{6-8}$ Du Preez utilized 1-decylimidazole to extract $\mathrm{Co}$ (II), $\mathrm{Ni}$ (II) and $\mathrm{Cu}$ (II) from their perchlorate, chloride and thiocyanate solutions. ${ }^{9}$ Recently, formation of the $\mathrm{Co}(\mathrm{II}), \mathrm{Ni}(\mathrm{II}), \mathrm{Cu}(\mathrm{II})$, and $\mathrm{Zn}$ (II) complexes with homologous series of 1-alkylimidazoles (with alkyl ranging from $\mathrm{C}_{4} \mathrm{H}_{9}$ through $\left.\mathrm{C}_{14} \mathrm{H}_{29}\right)$ has been studied by the partition method. ${ }^{10-13}$ Stability constants of the metal complexes in water have been determined as well as the partition ratios of species, which passed to the organic phase.

\section{COMPOUNDS WITH 1-ALKYLIMIDAZOLES}

The purpose of this contribution was to establish the conditions for selective extraction of the $\mathrm{Co}$ (II), $\mathrm{Zn}$ (II), $\mathrm{Ni}$ (II), and $\mathrm{Cu}$ (II) ions from aqueous solutions using alkylimidazoles as extractants.
All the studies were carried out at $298 \mathrm{~K}$ at constant ionic strength of the aqueous phase equal to $0,5 \mathrm{kept}$ by $\mathrm{KNO}_{3}$ and $\mathrm{HNO}_{3}$. The extraction measurements were carried out after adding an equal volume of organic solution of variable concentrations of 1-alkyl- or 1,2-dialkylimidazoles to the water phase containing $1 \mathrm{mM}$ investigated metal ions (Co(II), $\mathrm{Ni}(\mathrm{II}), \mathrm{Cu}(\mathrm{II})$, $\mathrm{Zn}(\mathrm{II})$ ). After the equilibrium was achieved, both phases were separated and the $\mathrm{pH}$ and metal ions concentration (by atomic absorption spectrophotometry) in the aqueous solution were measured.

To elaborate these conditions for the selective extraction of $\mathrm{Co}(\mathrm{II}), \mathrm{Zn}(\mathrm{II})$, and $\mathrm{Cu}$ (II) an attempt has been made to carefully scrutinize our results of investigations into the stability and extraction capacity of transition metal complexes with alkylimidazoles.

The stability constants of all the 1-alkylimidazole complexes with $\mathrm{Cu}(\mathrm{II})$ are constant and independent of the alkyl length and $p K a$ of the 1-alkylimidazole base.

Stabilities of the Co(II), Zn(II), and Ni(II) complexes have been found to increase with increasing the alkyl chain length of 1-alkylimidazoles. ${ }^{10-12}$ These dependences are lineal. The straight line dependence of the $\log \beta_{n}$ of $\mathrm{Co}(\mathrm{II}), \mathrm{Ni}(\mathrm{II})$, and the $\mathrm{Zn}$ (II) complexes with 1-alkylimidazoles as a function of the carbon atoms (x) in the group of alkyl chain in 1-alkylimidazole are presented in Table 1 .

Stability constants of the $\mathrm{Cu}$ (II) complexes are considerably higher than those of Co(II), Ni(II), and $\mathrm{Zn}$ (II). This may be explained in terms of a larger contribution of the $\pi_{\mathrm{M} \rightarrow \mathrm{L}}$ back donation to interaction of $\mathrm{Cu}(\mathrm{II})$ with the imidazole ring. The 1-alkyl substituent does not significantly affect either the polarization of the imidazole ring or the energy of its antibonding $\pi$ orbitals. ${ }^{1}$ It can thus be assumed that the contribution of the $\pi_{\mathrm{M} \rightarrow \mathrm{L}}$ bonding is invariable in the $\mathrm{Cu}(\mathrm{II})$ complexes with all the 1-alkylimidazoles. Partition of metal between the organic and aqueous phases was characterized by a ratio of metal partition as a function of the $\mathrm{pH}$ of the aqueous phase. The socalled distribution ratio, $D_{M}$, of the metal ion was derived from the measured concentrations and calculated from:

$D_{M}=\frac{C_{M e(I I)(o r g)}}{C_{M e(I I)(a q)}}=\frac{C_{M}^{0}-C_{M}}{C_{M}}$ 
Table 1. Comparison of the stability constants $\beta_{n}$ of $\mathrm{Co}(\mathrm{II}), \mathrm{Ni}(\mathrm{II}), \mathrm{Cu}(\mathrm{II})$, and $\mathrm{Zn}(\mathrm{II})$ complexes with 1-alkylimidazoles

\begin{tabular}{|l|c|c|c|c|}
\hline $\log \beta_{n}$ & $\mathrm{Co}(I I)^{[10]}$ & $\mathrm{Ni}(I I)^{[12]}$ & $\mathrm{Cu}(\mathrm{II})^{[13]}$ & $\mathrm{Zn}(\mathrm{II})^{[11]}$ \\
\hline $\log \beta_{1}$ & $\mathrm{y}=0.302 \mathrm{x}+1.653$ & $\mathrm{y}=0.161 \mathrm{x}+2.631$ & 4.15 & $\mathrm{y}=0.229 \mathrm{x}+1.986$ \\
\hline $\log \beta_{2}$ & $\mathrm{y}=0.342 \mathrm{x}+3.592$ & $\mathrm{y}=0.164 \mathrm{x}+5.290$ & 7.57 & $\mathrm{y}=0.229 \mathrm{x}+4.500$ \\
\hline $\log \beta_{3}$ & $\mathrm{y}=0.377 \mathrm{x}+4.881$ & $\mathrm{y}=0.164 \mathrm{x}+7.233$ & & $\mathrm{y}=0.229 \mathrm{x}+6.700$ \\
\hline $\log \beta_{4}$ & $\mathrm{y}=0.434 \mathrm{x}+5.780$ & $\mathrm{y}=0.166 \mathrm{x}+8.653$ & & \\
\hline
\end{tabular}

where: $C_{M}^{0}$ and $C_{M}$ denote analytical concentrations of the metal ions in the aqueous phase before and after attaining partition equilibrium, respectively.

The extraction process of the complexes is described by the equation (2):

$$
D_{M}=\frac{P_{c} \beta_{c}[L]^{c}+P_{c+1} \beta_{c+1}[L]^{c+1}+\ldots . .+P_{N} \beta_{N}[L]^{N}}{\sum_{n=0}^{n=N} \beta_{n}[L]^{n}}
$$

where: $\beta_{n}$ and $\beta_{c}$ are cumulative stability constants of the complexes in the aqueous phase, $P_{c}$ are organic solvent/ water partition ratios of the complexes, $\left(P_{c}=\left[\mathrm{ML}_{\mathrm{c}}\right](\mathrm{org}) /\right.$ $\left.\left[\mathrm{ML}_{\mathrm{c}}\right]_{(\mathrm{aq})}\right),[L]$ is the free ligand concentration $(\mathrm{mol} / \mathrm{L})$ in the aqueous phase and $c$ is the number of ligands molecules in the first complex that is so hydrophobic that it freely passes into the organic phase. ${ }^{\mathbf{1 4}, 15}$

The required free azole base concentrations in the aqueous phase at equilibrium, $[L]$, were found from the following equation:

$[L]=\frac{K_{a}\left[H L^{+}\right]}{\left[H_{3} O^{+}\right]}$

where $K_{a}$ is the dissociation constant of the protonated ligand $\mathrm{HL}^{+},\left[\mathrm{HL}^{+}\right]$is the concentration of the conjugate acid of the ligand equal to the analytical concentration of nitric acid $(\mathrm{mol} / \mathrm{L})$ in the aqueous phase. The $p K_{a}$ values of the alkylimidazoles needed for the calculations were taken from reference. ${ }^{3}$

With each solvent the extraction curves $\left(\log D_{\mathrm{M}}=\mathrm{f}(p H)\right)$ are distinctly displaced toward lower $\mathrm{pH}$ values with increasing the alkyl chain length of 1-alkylimidazole. In other words, the magnitude of $\mathrm{pH}_{1 / 2}$ for the partition ratio of metal(II), $\log D_{\mathrm{M}}=1$, decreases with increasing the number of methylene groups in 1-alkyl. An example of this type of shifting is presented in Fig. 2.

Partition ratio, $P_{n}$, of the metal complexes depends on the hydrophobic properties of an alkylimidazole and the nature of the solvent. The influence of the alkyl chain length of alkylimidazoles on partition ratios for methylene chloride and 2-ethylhexanol are presented in Fig.3 and Fig.4, respectively.

On the complexes formed in the aqueous phase, those with the coordination imidazole number of 1 up to $\leq 4$ were extracted. As it can be seen in Figs 3 - 4, the partition ratios of the first and second partition steps are small for $\mathrm{Co}$ (II) and $\mathrm{Zn}(\mathrm{II})$. This means that the extraction process is controlled by the stability and the partition ratios of the third and fourth complex. The partition constants for the Ni(II) complexes are higher than those of their $\mathrm{Co}$ (II) and $\mathrm{Zn}$ (II) counterparts in the absence of tetrahedral species in the aqueous solution. Readily extractable tetrahedral complexes of $\mathrm{Co}$ (II) occur in the second, third, and fourth complexation steps. Thus, in this case, the partition ratios, in particular $P_{3}$ and $P_{4}$, are higher than those of analogous $\mathrm{Ni}(\mathrm{II})$ compounds. With $\mathrm{Zn}(\mathrm{II})$, the tetrahedral complexes occur at the lower stages of the complexation process. Consequently, the partition ratios of the complexes with 2 and 3 ligands $\left(P_{2}\right.$ and $P_{3}$ respectively) are higher than those of the $\mathrm{Ni}(\mathrm{II})$ counterparts.

In the case of $\mathrm{Co}$ (II) and $\mathrm{Zn}$ (II) complexes with 1alkylimidazoles both tetra- and hexa-coordinate species occur in the aqueous phase. This results in the following configurational octahedron $\leftrightarrow$ tetrahedron equilibria:

in the case of $\mathrm{Co}(\mathrm{II})$ complexes:

$\left[\mathrm{CoL}_{3}\left(\mathrm{H}_{2} \mathrm{O}\right)_{3}\right]^{2+} \leftrightarrow\left[\mathrm{CoL}_{3}\left(\mathrm{H}_{2} \mathrm{O}\right)\right]^{2+}+2 \mathrm{H}_{2} \mathrm{O}$

$\left[\mathrm{CoL}_{4}\left(\mathrm{H}_{2} \mathrm{O}\right)_{2}\right]^{2+} \leftrightarrow\left[\mathrm{CoL}_{4}\right]^{2+}+2 \mathrm{H}_{2} \mathrm{O}$

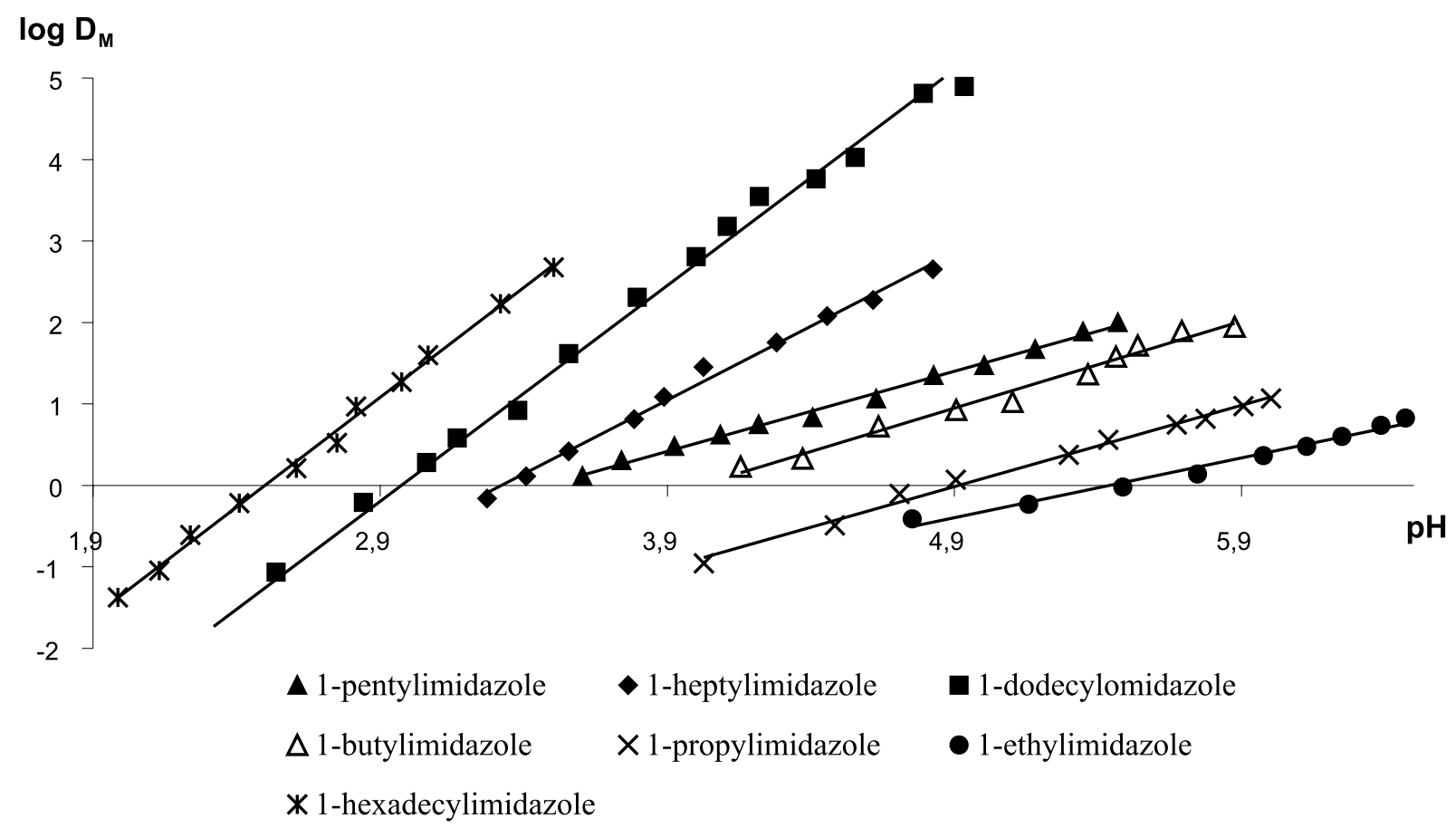

Figure 2. The influence of the alkyl chain length of 1-alkylimidazoles on the extraction of $\mathrm{Cu}(\mathrm{II})$ complexes into 2-ethylhexanol 


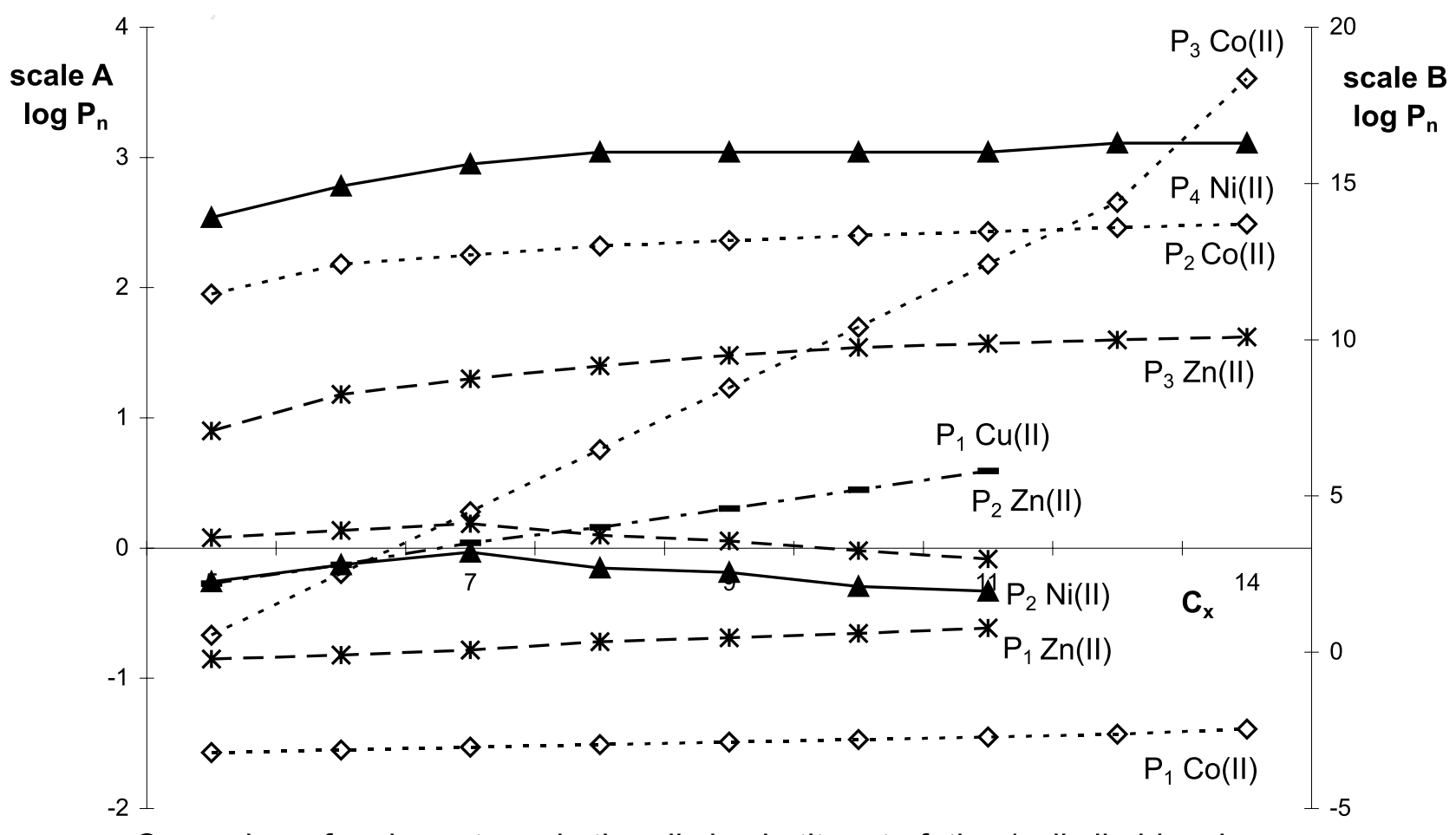

Figure 3. The influence of the alkyl chain length on the partition ratios $\left(P_{n}\right)$ of $\mathrm{Co}(\mathrm{II}), \mathrm{Ni}(\mathrm{II}), \mathrm{Cu}(\mathrm{II})$, and $\mathrm{Zn}(\mathrm{II}) \mathrm{complexes}$ with 1-alkylimidazoles for methylene chloride [scale B - for $\log P_{3}$ of $\mathrm{Co}(\mathrm{II})$ - 1-alkylimidazole complexes]

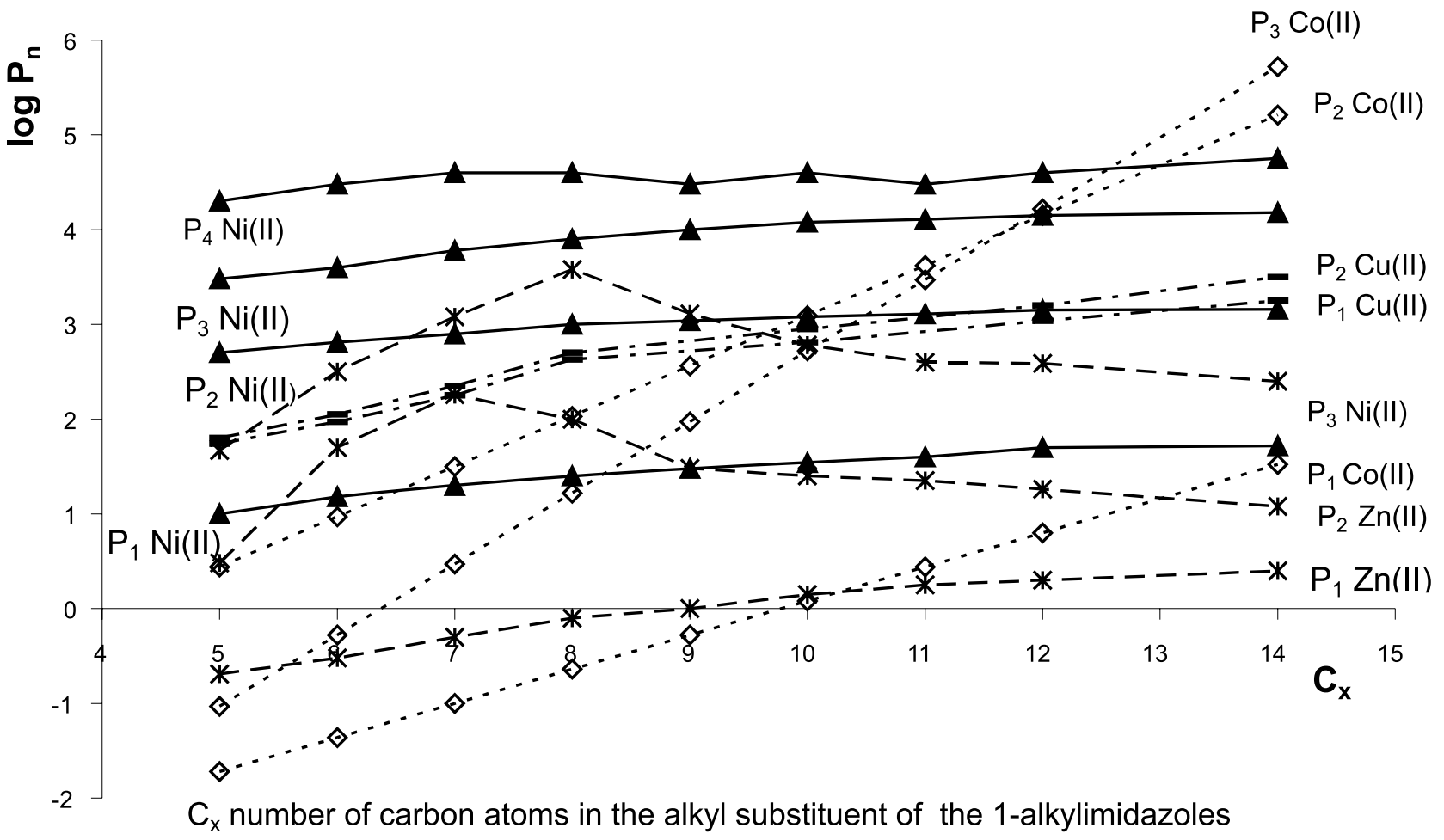

Figure 4. The influence of the alkyl chain length on the partition ratios $\left(P_{n}\right)$ of $\mathrm{Co}(\mathrm{II}), \mathrm{Ni}(\mathrm{II}), \mathrm{Cu}(\mathrm{II})$, and $\mathrm{Zn}(\mathrm{II})$ complexes with 1-alkylimidazoles for 2-ethylhexanol

in the case of $\mathrm{Zn}$ (II) complexes:

$\left[\mathrm{ZnL}_{2}\left(\mathrm{H}_{2} \mathrm{O}\right)_{4}\right]^{2+} \leftrightarrow\left[\mathrm{ZnL}_{2}\left(\mathrm{H}_{2} \mathrm{O}\right)_{2}\right]^{2+}+2 \mathrm{H}_{2} \mathrm{O}$

$\left[\mathrm{ZnL}_{3}\left(\mathrm{H}_{2} \mathrm{O}\right)_{3}\right]^{2+} \leftrightarrow\left[\mathrm{ZnL}_{3}\left(\mathrm{H}_{2} \mathrm{O}\right)\right]^{2+}+2 \mathrm{H}_{2} \mathrm{O}$,

where $\mathrm{L}$ - molecule of 1-alkylimidazoles.

Formation of the tetrahedral complexes enhances the extraction of $\mathrm{Co}(\mathrm{II})$ and $\mathrm{Zn}(\mathrm{II})$. The magnitudes of $P_{1}$ and $P_{2}$ suggest that the extraction of $\mathrm{Cu}$ (II) from the aqueous phase with 1alkylimidazoles is controlled mostly by the first (ML) and second $\left(\mathrm{ML}_{2}\right)$ species. Again, under comparable conditions, the extraction of $\mathrm{Co}(\mathrm{II}), \mathrm{Ni}(\mathrm{II})$, and $\mathrm{Zn}(\mathrm{II})$ depended on the partition ratios of either three or four complexes..$^{10-12}$

The aforementioned scrutiny has shown that:

(i) Elongation of the alkyl chain of the 1-alkylimidazole molecule (i.e. strengthening their hydrophobicity) is favourable for the extraction efficiency of the complexes on account of increasing their stability and partition constants.

(ii) 1-Alkylimidazoles with more than nine carbon atoms in the alkyl chain can be used for the separation of $\mathrm{Co}(\mathrm{II}), \mathrm{Zn}(\mathrm{II})$, 


\begin{tabular}{|c|c|c|c|c|c|c|c|}
\hline Ligand ${ }^{\text {literature] }}$ & pKa & $\mathrm{Me}^{\mathrm{nt}}$ & $\log \beta_{1}$ & $\log \beta_{2}$ & $\log \beta_{3}$ & $\log \beta_{4}$ & $\log \beta_{5}$ \\
\hline 1,2-dimethyimidazole ${ }^{[21]}$ & 8.21 & $\begin{array}{l}\mathrm{Co}^{2+} \\
\mathrm{Ni}^{2+} \\
\mathrm{Zn}^{2+} \\
\mathrm{Cu}^{2+}\end{array}$ & $\begin{array}{l}1.13 \\
2.15 \\
1.92 \\
3.70\end{array}$ & $\begin{array}{l}2.39 \\
3.55 \\
4.32 \\
6.80\end{array}$ & $\begin{array}{l}3.81 \\
4.24 \\
7.11 \\
9.18\end{array}$ & $\begin{array}{c}4.32 \\
\\
9.00 \\
10.8\end{array}$ & $\begin{array}{r}9.62 \\
11.7\end{array}$ \\
\hline 1-ethyl-2-methylimidazole ${ }^{[21]}$ & 8.21 & $\begin{array}{l}\mathrm{Co}^{2+} \\
\mathrm{Ni}^{2+} \\
\mathrm{Zn}^{2+} \\
\mathrm{Cd}^{2+} \\
\mathrm{Cu}^{2+}\end{array}$ & $\begin{array}{l}1.40 \\
1.88 \\
1.11 \\
2.28 \\
3.52\end{array}$ & $\begin{array}{l}1.88 \\
3.43 \\
4.45 \\
3.94 \\
6.60\end{array}$ & $\begin{array}{l}3.55 \\
3.37 \\
7.11 \\
4.62 \\
8.98\end{array}$ & $\begin{array}{r}9.05 \\
10.3\end{array}$ & \\
\hline 1-propyl-2-methylimidazole ${ }^{[21]}$ & 8.25 & $\begin{array}{l}\mathrm{Co}^{2+} \\
\mathrm{Ni}^{2+} \\
\mathrm{Zn}^{2+} \\
\mathrm{Cd}^{2+} \\
\mathrm{Cu}^{2+}\end{array}$ & $\begin{array}{l}1.61 \\
2.05 \\
2.35 \\
2.56 \\
3.67\end{array}$ & $\begin{array}{l}2.00 \\
2.41 \\
4.40 \\
4.06 \\
7.23\end{array}$ & $\begin{array}{l}3.08 \\
4.19 \\
7.45 \\
5.57 \\
9.65\end{array}$ & $\begin{array}{r}5.40 \\
9.41 \\
12.0\end{array}$ & 10.4 \\
\hline 1-butyl-2-methylimidazole $\left.{ }^{[21}\right]$ & 8.18 & $\begin{array}{l}\mathrm{Co}^{2+} \\
\mathrm{Ni}^{2+} \\
\mathrm{Zn}^{2+} \\
\mathrm{Cd}^{2+} \\
\mathrm{Cu}^{2+}\end{array}$ & $\begin{array}{l}1.73 \\
2.03 \\
1.20 \\
2.44 \\
3.74\end{array}$ & $\begin{array}{l}2.08 \\
3.49 \\
4.96 \\
4.02 \\
6.98\end{array}$ & $\begin{array}{l}2.76 \\
4.54 \\
6.97 \\
5.37 \\
9.44\end{array}$ & $\begin{array}{c}5.65 \\
5.00 \\
9.73 \\
6.03 \\
11.3\end{array}$ & 10.6 \\
\hline 1-pentyl-2-methylimidazole ${ }^{[22,23]}$ & 8.27 & $\begin{array}{l}\mathrm{Zn}^{2+} \\
\mathrm{Cu}^{2+}\end{array}$ & $\begin{array}{l}3.07 \\
3.50\end{array}$ & 6.59 & 9.18 & & \\
\hline 1-hexyl-2-methylimidazole ${ }^{[22,23]}$ & 8.32 & $\begin{array}{l}\mathrm{Zn}^{2+} \\
\mathrm{Cu}^{2+}\end{array}$ & $\begin{array}{l}3.48 \\
3.52\end{array}$ & $\begin{array}{l}5.80 \\
6.63\end{array}$ & $\begin{array}{l}8.30 \\
8.98\end{array}$ & 10.1 & \\
\hline 1-octyl-2-methylimidazole ${ }^{[22,23]}$ & 8.40 & $\begin{array}{l}\mathrm{Zn}^{2+} \\
\mathrm{Cu}^{2+}\end{array}$ & $\begin{array}{l}4.45 \\
3.53\end{array}$ & $\begin{array}{l}6.80 \\
6.65\end{array}$ & $\begin{array}{l}9.10 \\
9.65\end{array}$ & & \\
\hline 1-nonyl-2-methylimidazole ${ }^{[22,23]}$ & 8.47 & $\mathrm{Zn}^{2+}$ & 4.75 & 7.15 & 9.50 & & \\
\hline 1-decyl-2-methylimidazole ${ }^{[22,23]}$ & 8.49 & $\begin{array}{l}\mathrm{Zn}^{2+} \\
\mathrm{Cu}^{2+}\end{array}$ & $\begin{array}{l}5.1 \\
3.54\end{array}$ & $\begin{array}{l}7.75 \\
6.68\end{array}$ & $\begin{array}{l}9.90 \\
9.44\end{array}$ & & \\
\hline 1-dodecyl-2-methylimidazole ${ }^{[22,23]}$ & 8.53 & $\begin{array}{l}\mathrm{Zn}^{2+} \\
\mathrm{Cu}^{2+}\end{array}$ & $\begin{array}{l}5.40 \\
3.58\end{array}$ & $\begin{array}{l}8.25 \\
6.75\end{array}$ & $\begin{array}{c}10.3 \\
9.37\end{array}$ & 10.9 & \\
\hline
\end{tabular}

Table 2. The stability constants of the 1-alkyl-2-methylimidazole complexes with $\mathrm{Co}(\mathrm{II}), \mathrm{Ni}(\mathrm{II}), \mathrm{Cu}(\mathrm{II}), \mathrm{Cd}(\mathrm{II})$ and $\mathrm{Zn}(\mathrm{II})$ at $298 \mathrm{~K}$, ionic strength $0.5 \mathrm{~mol} / \mathrm{L}\left(\mathrm{KNO}_{3}\right)$

and $\mathrm{Cu}(\mathrm{II})$ from $\mathrm{Ni}$ (II) and other six-coordinate cations that do not change their coordination numbers. At the same time, there is an opportunity of predicting an optimum $\mathrm{pH}$ for each extractant (1-alkylmidazole) and the selection of the most effective solvent.

\section{COMPOUNDS WITH}

\section{1-ALKYL-2-METHYLIMIDAZOLES}

Further, let us consider what changes in the extraction process of the metal complexes can be expected by the substitution of an alkyl in position 2 of the 1-alkylimidazole molecule.

Substitution of the methyl group in position 2 of the imidazole ring increases by an order of magnitude the basicity of the pyridinic nitrogen atom. At the same time the subsituent hampers the formation of the 2-methylimidazole complexes with metal ions due to the steric hindrance. Lowering of the stability of the metal complexes due to steric hindrance depends on the nature of the central ion, as well. The largest decrease in the stability has been noticed for 2-methylimidazole complexes of $\mathrm{Ni}(\mathrm{II})$, a lightly smaller for octahedral species of $\mathrm{Co}(\mathrm{II})$ and $\mathrm{Zn}(\mathrm{II})$, and the smallest one for $\mathrm{Cu}(\mathrm{II}) .^{\mathbf{1 6}-20}$ The substitution of bulky alkyl groups in position 1 results in enhanced hydrophobicity of the imidazoles, thus providing an opportunity for the extraction of metal complexes of these bases with organic solvents. ${ }^{\mathbf{2 1}}$

The stability constants (Table 2) of $\mathrm{Co}(\mathrm{II}), \mathrm{Ni}(\mathrm{II})$, and $\mathrm{Zn}$ (II) complexes with 1-alkyl-2-methylimidazole formed in the aqueous phase increased with increasing the chain length of 1-alkyl substituents. The $\mathrm{Cu}$ (II) complexes with 1-alkyl-2methylimidazole are invariant, regardless of the alkyl chain length and $p K_{a}$ of the imidazole base. ${ }^{21,22}$ The partition ratios of metal ions complexes, $P_{n}$, are collected in Table 3.

In aqueous solutions of $\mathrm{Co}(\mathrm{II}), \mathrm{Zn}(\mathrm{II})$, and probably $\mathrm{Cd}(\mathrm{II})$, due to the operating steric effect, the complexes with the coordination number 6 are accompanied by those with the coordi- nation number 4. Consequently, for each of those cations an octahedron $\leftrightarrow$ tetrahedron equilibrium is set up:

$\left[\mathrm{MeL}_{\mathrm{n}-1}\left(\mathrm{H}_{2} \mathrm{O}\right)_{6-\mathrm{n}}+1\right]^{2+}+\mathrm{L} \leftrightarrow\left[\mathrm{MeL}_{\mathrm{n}}\left(\mathrm{H}_{2} \mathrm{O}\right)_{4-\mathrm{n}}\right]^{2+}+3 \mathrm{H}_{2} \mathrm{O}$, where: $\mathrm{L}$ - molecule of 1-alkyl-2-methylimidazoles, and 1 $\leq \mathrm{n} \leq 4$, $\mathrm{n}$ depends not only on the nature of the ligand but also on the electronic structure of the central ion.

All extractable $\mathrm{Cu}$ (II) complexes are hexacoordinate.

In the case of $\mathrm{Co}$ (II) complexes with 1-alkyl-2methylimidazole $\left[\mathrm{CoL}_{\mathrm{n}}\right]$ in solutions tetrahedral complexes are formed already for the second $n=2$ and the third $n=3$ complexation step. It can thus be suggested that the extractable species have the following composition: $\left[\mathrm{CoL}_{2} \mathrm{~S}_{2}\right]$, and $\left[\mathrm{CoL}_{3} \mathrm{~S}\right]$, where $\mathrm{S}$ denotes a solvent molecule. For $\mathrm{Zn}(\mathrm{II})$ complexes the greatest concentration of tetrahedral complexes was observed for $n=3$. The $\mathrm{Cd}(\mathrm{II})$ ion hardly changed the coordination number from 6 to 4 for $n=3$ and 4 .

The Ni(II) ions have a scarcely deformable octahedral coordination sphere. Consequently, the steric effect dramatically reduces the stability constants but only those of the octahedral complexes, e.g. of Ni(II) (Table 2).

The coordination sphere of the $\mathrm{Cu}(\mathrm{II})$ ion is extremely prone to deformation in such a way that the linkage of that ion to the pyridinic nitrogen of the imidazole ring is relatively short, and thus notably strong, this being reflected by high stability constant values.

With the $\mathrm{Co}$ (II) and $\mathrm{Zn}$ (II) ions, the steric effect impedes the formation of the octahedral species, while much less the tetrahedral ones. Again, the formation of the tetrahedral complexes of the metals, $\left[\mathrm{CoL}_{4}\right]$ and $\left[\mathrm{ZnL}_{4}\right]$, increases the complexation capacity of the metals as manifesting itself in their high stability constants, $\beta_{n}$, being the sum of the stability constants of the octahedral and tetrahedral complexes $\left(\beta_{\mathrm{n}}=\beta_{\mathrm{n} \text { (octahedral) }}+\right.$ $\beta_{\mathrm{n}(\text { tetrahedral })}$ ).

Owing to the combined hydrophobic and steric effects, 1alkyl-2-methylimidazoles paved the way to the separation of the metal ions. 
Table 3. The partition ratios $P_{n}\left(T=298 \mathrm{~K}, \mathrm{I}=0.5 \mathrm{~mol} / \mathrm{L}\left(\mathrm{KNO}_{3}\right)\right)$ of the metal complexes with 1-alkyl-2-methylimidazole

\begin{tabular}{|c|c|c|c|c|c|c|}
\hline Ligand $^{\text {[Literature] }}$ & $\mathrm{Me}^{\mathrm{n+}}$ & $\mathrm{P}_{1}$ & $\mathrm{P}_{2}$ & $\mathrm{P}_{3}$ & $\mathrm{P}_{4}$ & solvent \\
\hline 1,2-dimethyimidazole ${ }^{[21]}$ & $\begin{array}{l}\mathrm{Co}^{2+} \\
\mathrm{Cu}^{2+} \\
\mathrm{Ni}^{2+} \\
\mathrm{Zn}^{2+}\end{array}$ & $\begin{array}{l}48.0 \\
3.0 \\
1.70 \\
5.0 \\
\end{array}$ & $\begin{array}{c}22.0 \\
9.0 \\
5.70 \\
291 \\
\end{array}$ & & & $\begin{array}{l}\text { benzyl alcohol } \\
\text { benzyl alcohol } \\
\text { benzyl alcohol } \\
\text { benzyl alcohol }\end{array}$ \\
\hline 1-ethyl-2-methylimidazole ${ }^{[21]}$ & $\begin{array}{l}\mathrm{Cu}^{2+} \\
\mathrm{Ni}^{2+} \\
\mathrm{Zn}^{2+} \\
\mathrm{Cd}^{2+}\end{array}$ & $\begin{array}{c}2.0 \\
130 \\
2.90 \\
\end{array}$ & $\begin{array}{c}27.0 \\
2.08 \\
303 \\
10.3\end{array}$ & $\begin{array}{c}12.0 \\
42.0 \\
1870 \\
582\end{array}$ & 10.0 & $\begin{array}{l}\text { benzyl alcohol } \\
\text { benzyl alcohol } \\
\text { benzyl alcohol } \\
\text { benzyl alcohol }\end{array}$ \\
\hline 1-propyl-2-methylimidazole ${ }^{[21]}$ & $\begin{array}{l}\mathrm{Co}^{2+} \\
\mathrm{Cu}^{2+} \\
\mathrm{Ni}^{2+} \\
\mathrm{Zn}^{2+} \\
\mathrm{Cd}^{2+}\end{array}$ & $\begin{array}{l}75.0 \\
\\
1.00 \\
0.05 \\
0.50 \\
\end{array}$ & $\begin{array}{c}3500 \\
4.10 \\
5.10 \\
98.5 \\
10.0\end{array}$ & $\begin{array}{l}27.0 \\
49.0 \\
30.5\end{array}$ & 80.0 & $\begin{array}{l}\text { benzyl alcohol } \\
\text { benzyl alcohol } \\
\text { benzyl alcohol } \\
\text { benzyl alcohol } \\
\text { benzyl alcohol }\end{array}$ \\
\hline 1-butyl-2-methylimidazole ${ }^{[21]}$ & $\begin{array}{l}\mathrm{Co}^{2+} \\
\mathrm{Cu}^{2+} \\
\mathrm{Ni}^{2+} \\
\mathrm{Zn}^{2+} \\
\mathrm{Cd}^{2+}\end{array}$ & 8.00 & $\begin{array}{l}40.0 \\
261 \\
250 \\
371\end{array}$ & $\begin{array}{r}3100 \\
251 \\
1000 \\
100 \\
2130 \\
\end{array}$ & $\begin{array}{l}931 \\
242\end{array}$ & $\begin{array}{l}\text { benzyl alcohol } \\
\text { benzyl alcohol } \\
\text { benzyl alcohol } \\
\text { benzyl alcohol } \\
\text { benzyl alcohol }\end{array}$ \\
\hline 1-pentyl-2-methylimidazole ${ }^{[22,23]}$ & $\begin{array}{l}\mathrm{Zn}^{2+} \\
\mathrm{Cu}^{2+}\end{array}$ & $\begin{array}{c}0.2 \\
0.5 \\
15 \\
1.2 \\
2.5 \\
\end{array}$ & $\begin{array}{r}2 \\
5 \\
271 \\
29 \\
15 \\
\end{array}$ & $\begin{array}{r}14 \\
8 \\
16 \\
458\end{array}$ & & $\begin{array}{l}p \text {-xylene } \\
\text { tetralin } \\
\text { methylene chloride } \\
\text { chloroform } \\
\text { 2-ethylhexanol }\end{array}$ \\
\hline 1-hexyl-2-methylimidazole ${ }^{[22,23]}$ & $\begin{array}{l}\mathrm{Zn}^{2+} \\
\mathrm{Cu}^{2+}\end{array}$ & $\begin{array}{c}0.6 \\
1 \\
26 \\
2.7 \\
4.0\end{array}$ & $\begin{array}{r}6 \\
15 \\
307 \\
35 \\
26\end{array}$ & $\begin{array}{r}75 \\
120 \\
150 \\
590\end{array}$ & 330 & $\begin{array}{l}p \text {-xylene } \\
\text { tetralin } \\
\text { methylene chloride } \\
\text { chloroform } \\
\text { 2-ethylhexanol }\end{array}$ \\
\hline 1-octyl-2-methylimidazole ${ }^{[22,23]}$ & $\begin{array}{l}\mathrm{Zn}^{2+} \\
\mathrm{Cu}^{2+}\end{array}$ & $\begin{array}{c}2 \\
10 \\
29 \\
2.9 \\
4.8 \\
\end{array}$ & $\begin{array}{r}50 \\
80 \\
346 \\
42 \\
38 \\
\end{array}$ & $\begin{array}{r}2000 \\
1800 \\
3200 \\
725\end{array}$ & & $\begin{array}{l}p \text {-xylene } \\
\text { tetralin } \\
\text { methylene chloride } \\
\text { chloroform } \\
\text { 2-ethylhexanol } \\
\end{array}$ \\
\hline 1-nonyl-2-methylimidazole ${ }^{[22,23]}$ & $\mathrm{Zn}^{2+}$ & $\begin{array}{r}4 \\
17 \\
\end{array}$ & $\begin{array}{l}100 \\
180\end{array}$ & $\begin{array}{l}1,8^{*} 10^{4} \\
6500^{-1}\end{array}$ & & $\begin{array}{l}p \text {-xylene } \\
\text { tetralin }\end{array}$ \\
\hline 1-decyl-2-methylimidazole ${ }^{[22,23]}$ & $\begin{array}{l}\mathrm{Zn}^{2+} \\
\mathrm{Cu}^{2+}\end{array}$ & $\begin{array}{l}10 \\
30 \\
41 \\
3.1 \\
6 \\
\end{array}$ & $\begin{array}{r}180 \\
300 \\
395 \\
50 \\
52 \\
\end{array}$ & $\begin{array}{c}9 * 10^{5} \\
1,4^{*} 10^{4} \\
1,5^{*} 10^{4} \\
840\end{array}$ & & $\begin{array}{l}p \text {-xylene } \\
\text { tetralin } \\
\text { methylene chloride } \\
\text { chloroform } \\
\text { 2-ethylhexanol }\end{array}$ \\
\hline 1-dodecyl-2-methylimidazole ${ }^{[22,23]}$ & $\begin{array}{l}\mathrm{Zn}^{2+} \\
\mathrm{Cu}^{2+}\end{array}$ & $\begin{array}{c}15 \\
50 \\
48 \\
3.2 \\
9.2\end{array}$ & $\begin{array}{r}240 \\
450 \\
432 \\
58 \\
65\end{array}$ & $\begin{array}{r}9,5^{\star} 10^{5} \\
2,5^{\star} 10^{4} \\
3^{*} 10^{4} \\
980\end{array}$ & $1,8^{*} 10^{9}$ & $\begin{array}{l}p \text {-xylene } \\
\text { tetralin } \\
\text { methylene chloride } \\
\text { chloroform } \\
\text { 2-ethylhexanol }\end{array}$ \\
\hline
\end{tabular}

\section{SUMMARY}

- The stability constants of the $\mathrm{Co}(\mathrm{II}), \mathrm{Ni}(\mathrm{II})$, and $\mathrm{Zn}(\mathrm{II})$ complexes formed in the aqueous phase increased with an increase of the 1-alkyl chain length of the 1,3-diazoles. The stability constants of all the 1-alkyl- and 1-alkyl-2methylimidazole complexes with $\mathrm{Cu}(\mathrm{II})$ are constant and independent of the alkyl length and $p K_{a}$ of the base. An increase in hydrophobicity of the ligands resulted in the increase in partition ratios of the complexes.

The extraction curves were shifted towards lower $\mathrm{pH}$ values with an increase of the 1-alkyl chain length. The lowest $\mathrm{pH}_{1 / 2}$ values were obtained for the metal ions complexes with 1tetradecylimidazole and 1-dodecyl-2-methylimidazole.

- The steric effect, due to the methyl group in position 2 of the imidazole ring, enables the formation of tetracoordinate $\mathrm{Co}(\mathrm{II}), \mathrm{Zn}(\mathrm{II})$, and $\mathrm{Cd}(\mathrm{II})$ complexes, thus facilitating the extraction of these cations.

- Owing to the combined hydrophobic and steric effects, 1alkyl-2-methylimidazoles paved the way to the separation of the
$\mathrm{Co}(\mathrm{II}), \mathrm{Zn}(\mathrm{II})$, and $\mathrm{Cu}(\mathrm{II})$ from other ions of metals. By the substitution of alkyl groups in position 1 or 2 of the imidazole ring it is possible to program the extraction properties of extractants and to control the selectivity of extraction.

\section{LITERATURE CITED}

1. Sundberg, R.J. \& Martin B.R. (1974). Interaction of Histidine and other Imidazole Derivatives with Transition Metal Ions in Chemical and Biological System. Chem. Rev. 74, 471-517. DOI: $10.1021 / \mathrm{cr60290a003.}$

2. Martel, A.E. \& Smith R.M. (1982). Critical Stability Constants, Plenum Press, New York.

3. Lenarcik, B.\& Ojczenasz P. (2002). The Infuence of the Size and Position of the Alkyl Groups in Alkylimidazole Molecules on Their Acid - Base Properties. J. Heterocyc. Chem. 39, 287 - 290. DOI: 10.1080/07366290601067572 .

4. Cupery, M.E. (1974). N-Imidazole Compounds and Their Complex Metal Derivatives. US Patent, 3843667, October 22.

5. Schakers, J.M. \& du Preez J.G.H. (2004) Solvent Extraction Mixture Comprising Substituted Imidazole or Benzimidazole for the Purification of Groups of Base Metals. US Patent, US 20040208808 A1, October 21. 
6. Lenarcik, B.\& Barszcz B. (1977). Stability and Structure of Transition Metal Complexes with Azoles in Aqueous Solutions. Part XIV. Complex Formation Between NMethylimidazole and $\mathrm{Co}(\mathrm{II}), \mathrm{Ni}(\mathrm{II}), \mathrm{Cu}(\mathrm{II})$ and $\mathrm{Zn}(\mathrm{II})$. Roczniki Chem. 51, 18491855.

7. Lenarcik, B.\& Barszcz B. (1979). Stability and Structure of Transition Metal Complexes with Azoles in Aqueous Solutions. Part XIX. Structural Effects During Complexation of $\mathrm{Co}(\mathrm{II}), \mathrm{Ni}(\mathrm{II}), \mathrm{Cu}(\mathrm{II})$ and $\mathrm{Zn}(\mathrm{II})$ with 1-Ethyl- and 1Propylimidazoles. Polish J. Chem. 53, 963 - 971.

8. Lenarcik, B., Barszcz B.\& Kulig J. (1977). Stability and Structure of Transition Metal Complexes with Azoles in Aqueous Solutions. Part XI. A Study on Complex Formation Between N-Butylimidazole and $\mathrm{Co}(\mathrm{II}), \mathrm{Ni}(\mathrm{II}), \mathrm{Cu}(\mathrm{II})$ and Zn(II). Roczniki Chem. 51, 1315 - 1322.

9. du Preez, J.G.H., Sumter N., Matteűs Ch., Ravindran S.\& van Brecht B.J. (1997). Nitogen Reagents in Metal Ion Separation. Part VII. The Development of a Novel Copper(II) Extractant. Sol. Extr. Ion Exch. 15, 1007 - 1021. DOI: 10.1080/ 07366299708934518.

10. Lenarcik, B.\& Ojczenasz, P. (2004). Investigation of the Stability Constants of $\mathrm{Co}(\mathrm{II})$ Complexes with a Homologous Series of 1-Alkylimidazoles in Aqueous Solution by Using a Partition Method with Several Solvents. Sep. Sci. Technol. 39, 199 - 226. DOI: 10.1081/SS-120027409.

11. Lenarcik, B. \& Kierzkowska, A. (2004). The Influence of Alkyl Length on Stability Constants of $\mathrm{Zn}$ (II) Complexes with 1-Alkylimidazoles in Aqueous Solutions and Their Partition Between Aqueous Phase and Organic Solvent. Sol. Extr. Ion Exch. 22, 449 - 471. DOI: 10.1081/SEI-120030398.

12. Lenarcik, B. \& Rauckyte, T. (2004). The Influence of Alkyl Length on Extraction Equilibria of Ni(II) Complexes with 1-Alkylimidazoles in Aqueous Solution/Organic Solvent Systems. Sep. Sci. Technol. 39, 3353 - 3372. DOI: 10.1081/SS200028915.

13. Radzyminska-Lenarcik E. (2007). The Influence of the Alkyl Chain Length on the Extraction Equilibrium of $\mathrm{Cu}(\mathrm{II})$ Complexes with 1-Alkylimidazoles in Aqueous Solution -Organic Solvent Systems. Solv. Ext. Ion Exch. 25, 53 - 64. DOI: 10.1080/07366290601067572.

14. Rydberg, J., Musakis C.K. \& Chopin, G.R. (1992). Principles and Practices of Solvent Extraction. M. Dekker Inc.

15. Rossotti, F.J.C. \& Rossotti, H. (1961). The Determination of Stability Constants. McGraw-Hill, New York

16. Lenarcik, B. \& Kurdziel, K. (1981). Stability and Structure of Transition Metal Complexes of Azoles in Aqueous Solutions. Part XXIII. Effect of the Position of Methyl Substituents on the Complex-Forming Capacity of Imidazoles. Polish J. Chem. 55, 737 - 745.

17. Lenarcik, B. \& Kurdziel, K. (1982). Stability and Structure of Transition Metal Complexes of Azoles in Aqueous Solutions. Part XXV. The Effect of the Size and Position of an Alkyl Substituent on the Stability and Structure of Alkylimidazole Complexes. Polish J. Chem. 56, 3 - 14.

18. Lenarcik, B., Kurdziel K. \& Czopek, R. (1991). Stability and Structure of Transition Metal Complexes with Azoles in Aqueous Solutions. Part XXIX. The Influence of the Size and Structure of the Alkyl Group on the Formation of 2Alkylimidazole Complexes. Polish J. Chem. 65, 1235 - 1241.

19. Lenarcik, B., Kulig J. \& Laidler, P. (1974). Stability and Structure of Transition Metal Complexes with Azoles in Aqueous Solutions. Part II. 2-Methylimidazole Complexes of $\mathrm{Co}(\mathrm{II}), \mathrm{Cu}(\mathrm{II})$ and $\mathrm{Zn}(\mathrm{II})$. Roczniki Chemii 48, 1151 - 1158.

20. Lenarcik, B. \& Barszcz, B. (1980). Stability and Structure of Transition Metal Complexes with Azoles in Aqueous Solutions. Part XXI. A Comparison of Complex-Forming of 1,2-Dimethylimidazole with that of Other 1,3-Diazoles. J. Chem. Soc. Dalton Trans. 24 - 28. DOI: 10.1039/DT9800000024.

21. Lenarcik, B., Adach A. \& Radzyminska-Lenarcik, E. (1999). The Influence of Steric Effect and Alkyl Chain Length on the Extraction of the Complexes of $\mathrm{Co}(\mathrm{II}), \mathrm{Ni}(\mathrm{II}), \mathrm{Cu}(\mathrm{II})$, $\mathrm{Zn}(\mathrm{II})$ and $\mathrm{Cd}(\mathrm{II})$ with 1-Alkyl-2-methylimidazoles. Polish $\mathrm{J}$. Chem. 73, 1273 - 1281.

22. Radzyminska-Lenarcik, E. (2007). Effect of Alkyl Chain Length on the Extraction of Copper(II) Complexes with 1Alkyl-2-methylimidazoles. Sep. Sci. Technol. 42, 2661 - 2676. DOI: $10.1080 / 01496390701515003$.

23. Lenarcik, B. \& Kierzkowska, A. (2006). The Influence of Alkyl Chain Length and Steric Effect on Extraction of Zinc(II) Complexes with 1-Alkyl-2-methylimidazoles. Sol. Extr. Ion Exch. 24, 433 - 445. DOI: 10.1080/07366290600646962. 